\title{
マイクロ構造における表面間力の測定と表面間力の低減
}

$$
\begin{aligned}
& \text { 土 谷 茂 樹*. 鈴 木 清 光** - 嶋 田 智** } \\
& \text { 三木 政 之**. 松 本 昌 大**.倉 垣 智** }
\end{aligned}
$$

\section{Measurement of the Surface Force in Micro Structures and Its Reduction}

\author{
Shigeki Tsuchitani*, Seiko Suzuki**, Satoshi ShImada** \\ Masayuki Miki**, Masahiro Matsumoto** and Satoru KuRAGAKI**
}

\begin{abstract}
In microstructures such as microsensors and microactuators, a small surface force can occur between two contacting surfaces which affects operations. Therefore, it is very important to clarify the generation mechanism of this surface force and to find a way to decrease it in the devices.

In this study, a microstructure used in evaluating surface force was fabricated by a silicon micromachining technique. This device has a movable plate supported by cantilever beams and two opposing electrodes positioned above and below the movable plate. The surface force acting at the contact area of the movable plate and the opposing electrodes was evaluated as follows: The movable plate made contact with one of the electrodes when an electrostatic force was applied. Then another electrostatic force was applied to remove the movable plate by applying a voltage between it and the other electrode. The surface force was calculated from the voltage needed to separate them. This method was applied to measure the surface force under various conditions in which the amount of water adsorbed on the surface was different.

It was confirmed that the surface force could be lowered by such measures as thermal treatment at about $200^{\circ} \mathrm{C}$ and hydrophobic treatment of the surface, which decreased the amount of water adsorbed on the surface from the atmosphere. This meant that interaction between the water molecules adsorbed on the surface was one of the main causes of the surface force.

Another way to lower surface force was to make the contact area of the movable plate and the electrodes samller. For example, pyramid type stoppers, formed on the movable plate, were very effective to decrease the surface force.
\end{abstract}

Key Words : microstructure, microsensor, microactuator, surface force, sticking force, water adsorption

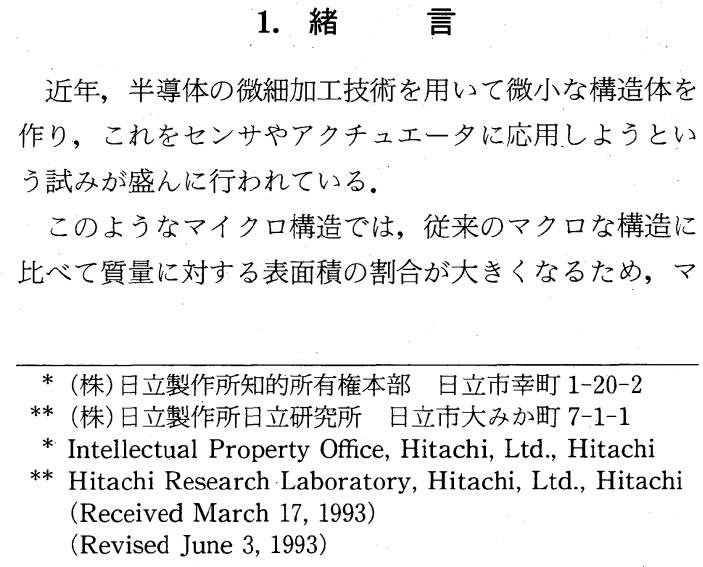

1. 緒

$\overline{\overline{\overline{\bar{一}}}}$

近年, 半導体の微細加工技術を用いて微小な構造体を 作り，これをセンサやアクチュエータに応用しようとい う試みが盛んに行われている。

このようなマイクロ構造では, 従来のマクロな構造に 比べて質量に対する表面積の割合が大きくなるため, マ

* (株) 日立製作所知的所有権本部 日立市幸町 1-20-2

** (株) 日立製作所日立研究所 日立市大みか町 7-1-1

* Intellectual Property Office, Hitachi, Ltd., Hitachi

** Hitachi Research Laboratory, Hitachi, Ltd., Hitachi (Received March 17, 1993)

(Revised June 3, 1993)

クロな構造体では問題にならなかった表面同士の間に働 く微小な表面間力が重要な役割を演じることが報告され ている，たとえば，基板上に形成した微小なモータでは 回転子と基板との間の表面間力に起因する摩擦力は回転 子の最大回転速度を決定するなどその動作に大きな影響 を及ぼす1),2). また, 梁あるいはダイアフラムを有する微 小素子では, 製作時あるいは動作時, 梁またはダイアフ ラムと対向基板とが接触した際表面間力によって両者が 付着したまま動作しなくなる場合がある゙,4). そこで, こ のような表面間力が発生するメカニズムを解明し, 表面 間力を低隇する対策を施すことがこれらのデバイスを実 用化する上で重要な課題となっている.

本論文では, 表面間力の評価用としてシリコンからな 
るカンチレバーによって支持された可動部とこれと対向 する対向電極とを有するサンプルを作成し，可動部と対 向電極とが接触した際に働く表面間力を可動部に静電気 力を加えて評価する方法について述べ，この評価方法を 各種条件，特に䨌囲気中に含まれる水分の素子表面への 吸着量が異なるような条件のもとでの表面間力の測定に 応用した結果を述べる.ささらに，この結果をもとに表面 間力発生のメカニズムについて議論する. 最後に, マイ クロ構造の接触領域に働く表面間力を低減する方法と し, 接触部分の形状を微小化して接触面積を低減するこ とが非常に有効であることを述べる。

\section{2. 各種表面間力}

マイクロセンサやマイクロアクチュエータと同じく微 小な物体，たとえば粉体などの微小な粒子同士に働く表 面間力としては，つぎの三つの力が最も基本的であると いわれている5).

(a) 静電引力

(b) ファン・デル・ワールスカ

(c) 液架橋力

静電引力は，二つの異なる物質が接近したとき，互い の仕事関数の違いによって電子の移動が起こることに よって生じる. 絶縁体同士の場合には十分な電子の移動 が期待できず, 表面から内部へかけて相当程度の電子の 蓄積が起こり，これが空間電荷層を形成すると同時に， 表面に過剰電荷を帯びさせることになり，この過剰電荷 によるクーロン力によって付着力が働く.

ファン・デル・ワールスカは，もともと分子(または原 子)間に作用する力であるが, 粒子と粒子, 粒子と壁など マクロな二物体がごく接近したときにも生じる電磁気的 力で, 主に二物体の電子の運動に依存する. ファン・デ ル・ワールス力は雾囲気や環境条件の影響をほとんど受 けないといわれている。

また，液架橋力は，二物体の近接部に液体が付着し， 面と面との間に架橋現象を生じたとき，表面張力および 毛管負圧によって発生するものである，大気中では液架 橋は主として大気中に多量に含まれる水分の吸着によっ て形成される。しかし, 最近の研究では, 雾囲気の湿度 の増加による表面への水分の吸着はほとんど無視しうる 量であって，たどえば 2 個の球体同士の場合，近接部へ の凹レンズ状の架橋状態は考えられないもかかわらず, 付着力が大幅に増大する傾向が示されている. したがっ て，実際には吸着層の作用として考えていかなければな らないとされている.

Sheeper ら ${ }^{4)}$ は $\mathrm{Si}_{3} \mathrm{~N}_{4}$ からなるカンチレバーを用いた 実験により，微小構造体において付着を引き起こす原因
となる表面間力は表面に吸着した水分子同士に働く引力 によるとした. $\mathrm{SiO}_{2}$ または $\mathrm{Si}_{3} \mathrm{~N}_{4}$ を水蒸気を含む通常の 大気中に放置すると表面に水分子が吸着される，最表面 には化学吸着された水によって水酸基 $(-\mathrm{OH})$ が形成さ れ，さらにその上に別の水分子が水素結合によって物理 吸着される，表面に水分子の吸着層を有する二つ構造体 が互いに接触すると，水分子同士の間に働く水素結合力 によって表面間力が発生するとしている.

一般に，通常の金属を大気中に放置するとその表面に は酸化層が形成され，さらにそこに水分子が化学吸着さ れて表面に水酸基が形成されるため，表面は親水性とな る.

物質表面への水の吸着はBET の吸着理論によって記 述され，全表面のうち単分子層によって覆われる表面の 割合 $R_{C}$ は次式で表わされる。

$$
R_{C}=\frac{C h}{1+(C-1) h}
$$

ここで, $h$ は相対湿度， $C$ は無次元の定数である.した がって, 相対湿度 $h$ を低減することにより水分子の吸着 量を低下させることができる。

\section{3. 表面間力の評価方法}

\section{1 サンプルの作成}

Fig. 1 に表面間力の評価に使用したサンプルの断面構 造を示す．単結晶シリコン基板の異方性エッチングを行 い，カンチレバーとその先端に設けた四角い平板状の可 動部(長さ $1.3 \mathrm{~mm}$, 幅 $1.8 \mathrm{~mm}$, 厚さ $0.2 \mathrm{~mm}$ ) を形成し た. 一方, 可動部の上下には微小な空隙(約 $3 \mu \mathrm{m}$ )を隔て て絶縁基板上にモリブデン薄膜の対向電極を形成した. 図示していないが,サンプルの内部は外部と通じており, 通常可動部および対向電極はサンプル外部と同じ雾囲気 に置かれる。

可動部の過大変位時に対向電極と直接電気的に接触す ることがないよう，可動部の対向電極と対向した面の四 隅には $\mathrm{SiO}_{2}$ からなるストッパを形成した。したがって， 可動部と対向電極とはストッパを介して接触することに なる. 平面形状が $150 \mu \mathrm{m}$ 角, $20 \mu \mathrm{m}$ 角, $10 \mu \mathrm{m}$ 角および

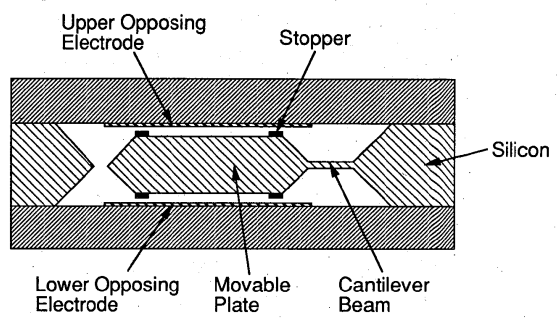

Fig. 1 Microstucture to evaluate surface force 
$5 \mu \mathrm{m}$ 角，高さがそれぞれ $0.4 \mu \mathrm{m}$ の 4 種類のストッパを 有するサンプルについて評価を行った。Fig. 2 Fig. 4 に(a) $20 \mu \mathrm{m}$ 角，（b） $10 \mu \mathrm{m}$ 角および(c) $5 \mu \mathrm{m}$ 角の

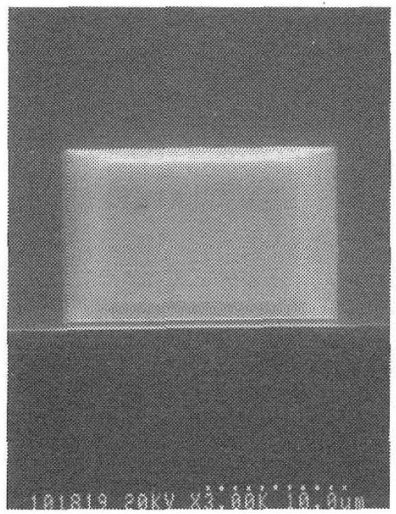

Fig. 2 SME photograph of a stopper (a) formed on the movable plate

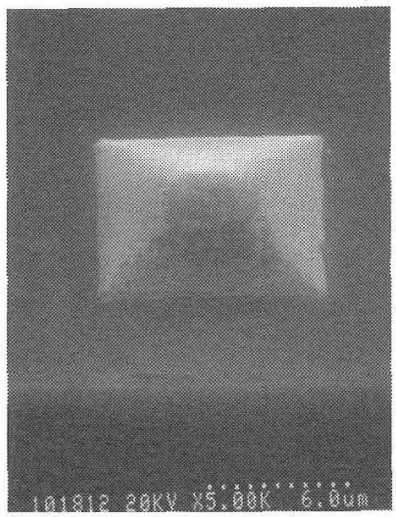

Fig. 3 SME photograph of a stopper (b) formed on the movable plate

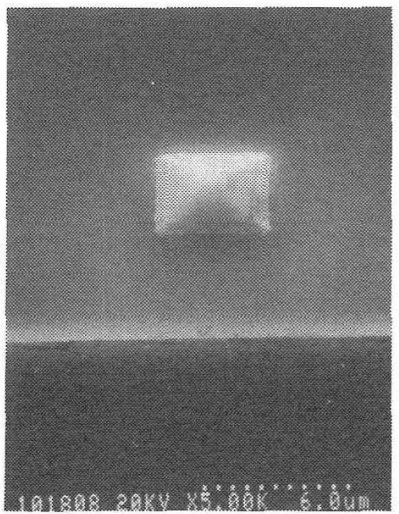

Fig. 4 SME photograph of a stopper (c) formed on the movable plate
3 種類ストッパの SEM 写真を示す。ストッパ(a)およ び(b)の上部には平坦な部分が存在し, 台形状となって いる。またストッパ(c)の上部には平坦な部分はなくピ ラミッド状となっており，ストッパ(a)，（b）に比べて 頂上部の面積は十分小さい。

\section{2 表面間力の評価方法}

Fig. 5 は, 上述のサンプルを使用し, 可動部と対向電極 とがストッパを介して接触した場合のストッパと対向電 極との表面間力を評価した評価回路のブロック図を示 す。そして表面間力をつぎの方法で求めた。

1) 中央の可動部と下側対向電極との間に電圧を印加 (たとえば，5 V , 5 s) し，静電気力によってストッパと 下側対向電極とを強制的に接触させる。電圧を解除す ると, カンチレバーの復元力に比べて表面間力のほう が大きければ接触状態は維持され，付着する。

2）付着した場合，可動部と上側対向電極との間に0 V から増加するランプ状の電圧を印加し, 可動部と下側 対向電極との付着状態を解除させようとする静電気力 を可動部に印加する。ただし，可動部に働く重力の対 向電極と直角方向の成分がゼロとなるようサンプルを 垂直に立てた状態で評価した。そして付着が解除する 瞬間の電圧 $V_{r}$ から以下に述べる計算によって表面間 力を求める。付着が解除したか否かは可動部と上側対 向電極との間の静電容量の変化から判断する。すなわ ち, 付着が解除した瞬間, 静電気力およびカンチレバ 一の復元力によって可動部が下側対向電極から急に離 れるため, 両者の距離に依存する静電容量が電压に対

してステップ状に増加する。

以上のように，可動部をいったん対向電極に付着させて 表面間力の測定を行うので, 特にカンチレバーの復元力 $\left(1.6 \times 10^{-5} \mathrm{~N}\right)$ に比べて表面間力のほうが大きなサンプ ルを用いて測定を行った。

つぎに，付着が解除する電圧 $V_{r}$ から表面間力 $F$ を求 める方法を Fig. 6 を用いて説明する。

表面間力が比較的小さい場合，可動部と対向電極との 付着はFig. 6 に示すように可動部の先端のストッパで のみ発生する。可動部の四隅に設けたストッパの全てを 対向電極と接触させるには，先端部のみを接触させた場

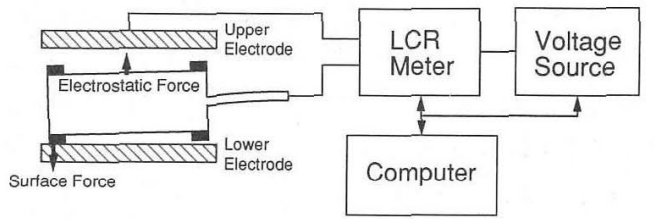

Fig. 5 Block diagram of the circuit to evaluate surface force 


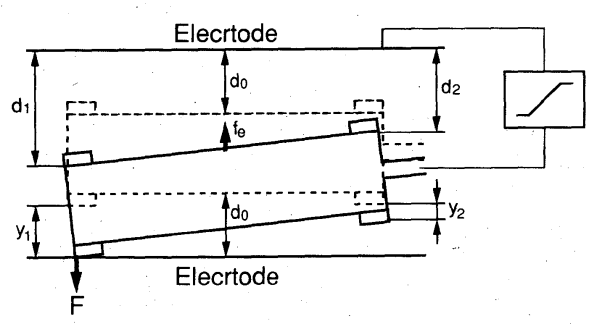

Fig. 6 Schematic for the calculation method of surface force

合に比べてょり大きなカンチレバーの復元力に打ち勝つ だけの表面間力が必要となる. Fig. 6 に示すように, 可動 部の中央に上向きに $f_{e}$ 以上の力を加えた時付着が解除 するとすると,材料力学に扔ける梁のたわみの計算から, 可動部先端のストッパと対向電極との表面間力 $F$ は 次式で与えられる.

$$
F=\frac{E b h^{3} y_{1}+l\left(4 l^{2}+9 l L+6 L^{2}\right) f_{e}}{4 l\left(l^{2}+3 l L+3 L^{2}\right)} .
$$

ただし, 可動部やカンチレバーに働く重力の影響を無視 した。ここで, $E$ は単結晶シリコンのヤング率 $\left(1.1 \times 10^{11}\right.$ $\left.\mathrm{N} / \mathrm{m}^{2}\right), b, h, l$ はそれぞれカンチレバー幅, 厚み, 長さ, $y_{1}$ は可動部先端のストッパの変位量, $L$ は可動部の長さ である。また付着解除時におけるカンチレバー側ストッ パの変位量 $y_{2}$ は次式で表わされる.

$$
y_{2}=\frac{\left\{4\left(F-f_{e}\right) l+3\left(2 F-f_{e}\right) L\right\} l^{2}}{E b h^{3}}
$$

一方, 可動部に印加される外力 $f_{e}$ は可動部と上側対向 電極との間に電圧を印加して静電気力によって与えられ る.電圧 $V_{r}$ で付着が解除したとすると,このときの可動 部と上側対向電極との静電気力 $f_{e}$ は簡単な電磁気学の 計算から次式で与えられる。

$$
\begin{aligned}
f_{e} & =-\frac{\varepsilon_{0} S V_{r}^{2}}{2 d_{1} d_{2}} \\
& =-\frac{\varepsilon_{0} S V_{r}^{2}}{2\left\{d_{0}^{2}+\left(y_{1}+y_{2}\right) d_{0}+y_{1} y_{2}\right\}}
\end{aligned}
$$

ここで, $S$ は可動部と対向電極との対向部の面積, $d_{0}$ は 可動部の変位がない状態での可動部と上下の対向電極と の間の空隙の大きさ， $d_{1}, d_{2}$ はそれぞれ可動部の付着解 除時に㧍ける可動部の先端部分扔よびカンチレバー側の 部分と上側対向電極との間の距離， $\varepsilon_{0}$ は真空の誘電率で ある. 静電気力 $f_{e}$ が Fig. 6 に示すように可動部の中央に 働くものと近似すると, (2) 式〜 ( 4 ) 式は $F, f_{e}, y_{2}$ を末 知数とする連立方程式となり，これを解くことによって 表面間力 $F$ を求めることができる.

\section{4. 実験結果とその検討}

今回の実験では，特に雲囲気の湿度や水分の吸着によ

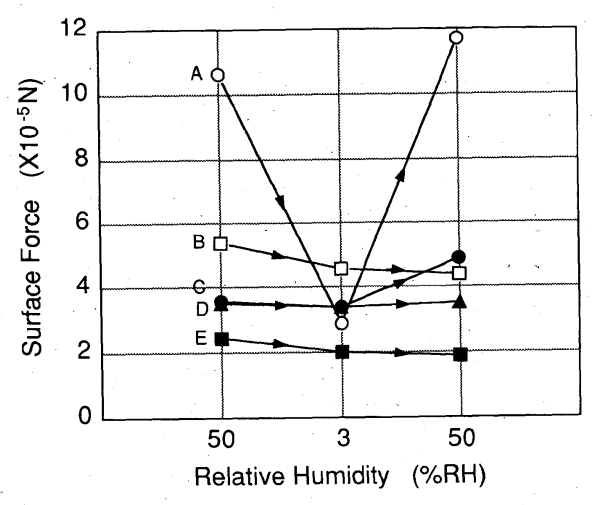

Fig. 7 Surface force vs. relative humidity

る表面間力への影響を評価した。

まず最初に表面間力に及ぼす湿度の影響を調べた。

Fig. 7 は，上述のサンプルを室内雾囲気および低湿状態 に放置したときの表面間力を比較した結果である.サン プルをステムに装着してパイプ付きのキャップを接着 し，パイプを真空ポンプにつないでステム内部を隇圧し ながら Fig. 5 に示した方法で表面間力を測定した。 サン プル内部の可動部および対向電極はステム内部と同じ湿 度状態に保たれる。最初に室内雾囲気(相対湿度約 $50 \%$ RH)で表面間力の測定を行い, つぎに減圧雲囲気 (6.7× $10^{3} \mathrm{~Pa}$ ，相対湿度約 $3 \% \mathrm{RH}$ ) 亿約 1 時間放置した後測定 を行い,さらに再び室内雲囲気に戻して測定を行った。 この実験では $150 \mu \mathrm{m}$ 角のストッパ付きサンプルを使用 した.

$50 \% \mathrm{RH}$ で最も表面間力が大きいサンプル A では $3 \%$ RH で力は約 $1 / 4$ に減少し，さらに $50 \% \mathrm{RH}$ に戻すと表 面間力はほほ元の值に復帰している。一方，ほかの 4 個 のサンプル B, C, D, Eでは $50 \% \mathrm{RH}$ と $3 \% \mathrm{RH}$ での表 面間力の変化はサンプル A の場合に比べてずっと小さ い.

ところで $\mathrm{SiO}_{2}$ 表面に化学吸着した水は約 $200^{\circ} \mathrm{C}$ まで は脱離されないが, その上に吸着した物理吸着水は $200^{\circ} \mathrm{C}$ 以下温度で加熱することによって除去すること ができるといわれている，そこで，サンプルの加熱処理 による表面間力への影響を調べた。 まず実験室雲囲気で 表面間力の測定を行った後, サンプルを $180^{\circ} \mathrm{C}$ 中で 90 時 間加熱し，その後サンプルを外界の䨌囲気から遮断して 水蒸気が侵入しないようにし, 室温まで泠却して再び表 面間力の測定を行った。この実験でも $150 \mu \mathrm{m}$ 角のスト ッパ付きサンプルを使用した。

実験結果を Fig. 8 亿示す.ただし, 表面間力がカンチ レバーの復元力より小さいサンプルについては表面間力 の大きさの範囲を棒線で示した。加熱処理を実施した後 


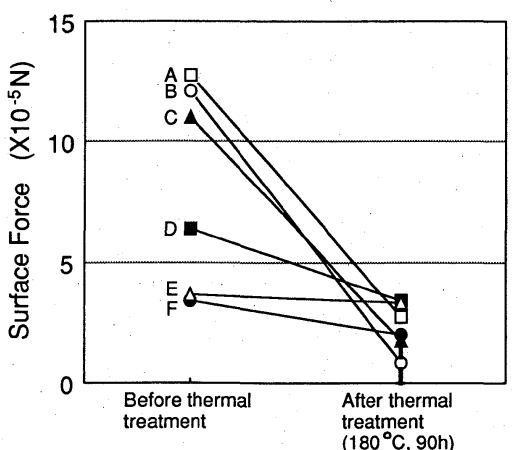

Fig. 8 Surface force before and after thermal treatment $\left(180^{\circ} \mathrm{C}, 90 \mathrm{~h}\right)$

では全てのサンプルで表面間力が減少しており，付着が 発生しなくなったサンプルも 1 個ある. 特に，加熱処理 前の表面間力が $10^{-4} \mathrm{~N}$ 以上の比較的大きなサンプルの ほうが表面間力がより小さなサンプルに比べて力の減少 率が大きい傾向がみられる，そして加熱処理後には全て のサンプルで表面間力が $4 \times 10^{-5} \mathrm{~N}$ 以下となっている.

つぎに, サンプルの表面に化学的な疎水化処理を行い， 表面間力への影響を評価した。疎水化処理によって表面 への水分子の吸着を防止することができる，表面処理に は半導体素子の製作時によく使用される HMDS (hexamethyldisilazane)を使用した。この化学処理により, $\mathrm{SiO}_{2}$ ストッパ表面または対向電極表面に水分子が化学 吸着することにようて形成される親水性の一 $\mathrm{OH}$ 基は疎 水性の $-\mathrm{O}-\mathrm{Si}\left(\mathrm{CH}_{3}\right)_{3}$ 基によって置換される.温度 $150^{\circ} \mathrm{C}$ に加熱したサンプルを HMDS の蒸気を充満させ た䨌囲気に放置し，HMDS 処理を行った。実験には 150 $\mu \mathrm{m}$ 角のストッパを有するサンプルを使用した。

Fig. 9 は, HMDS による疎水化処理を行う前後での表 面間力および処理後 5 日間大気中に放置した後の表面間 力の測定結果を示す. 処理直後, 10 個のサンプルのうち 9 個のサンプルで表面間力が減少し，うち 3 個で付着が 発生しなくなっている．処理後さらに大気中に 5 日間放 置すると 4 個のサンプルで表面間力が再び増加してい る.これは, 新たな水分子の化学吸着によって $-\mathrm{OH}$ 基が 形成され，ここに水分子の物理吸着が起こったためでは ないかと考えられる。

以上のように素子表面への水分子の吸着を抑える各種 処理を施すことによって表面間力を低減できることを定 量的に確認でき，表面への吸着水が表面間力に大きな寄 与をしていることがわかった。吸着水による表面間力の 発生はおそらくScheeper ら ${ }^{4)}$ がいうように物理吸着水 同士の間に働く力(水素結合力)によるものと考えられ る.特にもともと表面間力が大きいサンプルでは湿度の

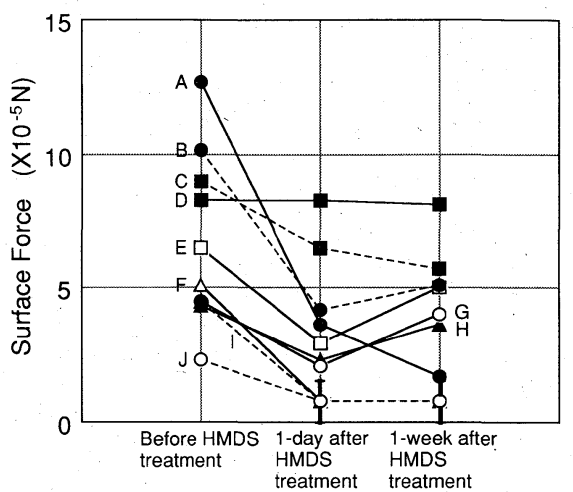

Fig. 9 Surface force before and after HMDS treatment

低減や加熱処理による表面間力の低下が大きく，吸着水 に起因する力が静電気力やファン・デル・ワールスカな どほかのメカニズムによるカと比べて寄与が大きいもの と推定される。

Fig. 7 亿示す減湿による表面間力の変化では，5 個の サンプルのうち 4 個で表面間力の変化は小さかった。こ のことから，単に湿度を数\% $\mathrm{RH}$ 程度まで減少させるだ けでは表面間力の低隇効果は不十分で，サンプルを長時 間高温加熱するなど表面の物理吸着水を十分除去する か，あるいは表面の疎水化処理などによって水分子の物 理吸着を防止しなければ十分な表面間力の低減は起こり 得ないものと考えられる。

ただし，上述の加熱処理や疎水化処理によっても全て のサンプルで表面間力を十分低減 (カンチレバーの復元 力より小さく)することはできなかった。これは，これら の処理がまだ不十分であったか, あるいはほかのメカニ ズムによる力が寄与しているためではないかと考えられ る.

以上の実験結果ではサンプルによって表面間力に大き なばらつきが見られる。これは，後述のように表面間力 には接触部表面のミクロな形状や粗度などが大きな影響 を及ぼし，これらが各サンプルで異なっているためであ ると考えられる。

\section{5. 表面間力の低減}

本章では, マイクロ構造に扔ける表面間力の低減方法 について述べる。

粉体工学の分野では，粒子間の表面間力に関して得ら れている重要な知見の一つは,「一般に物質の種類による 表面間力の差よりも粒子の形状や表面の粗度などの影響

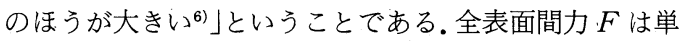
位面積当りの表面間力 $f$ と接触面積 $S$ との積に等しく, 粒子の形状や表面の粗度は接触面積 $S$ に影響を及ぼす 


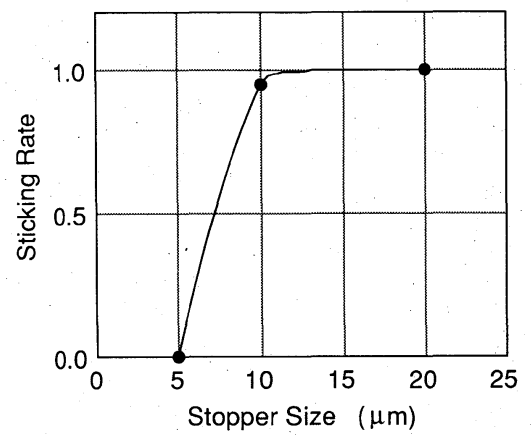

Fig. 10 Stopper size dependence of sticking rate

ものであるということがいえる．

したがって，マイクロ構造における表面間力を低隇す る方法を大きく分けるとつぎの二つが考えられる。

（a）表面間力発生の大きな原因と考えられる物理吸着 水を十分低減する構造とすること，あるいは材料を 用いること.

（b）接触面積を十分低減できるような接触部の形状， あるいは表面粗さとすること.

今回, 上記 $(b)$ の方法に関連し, 接触部すなわち $\mathrm{SiO}_{2}$ ストッパの形状, 特にストッパの大きさが表面間力に与 える影響を調べた。

第 2 章で述べた平面形状が $20 \mu \mathrm{m}$ 角, $10 \mu \mathrm{m}$ 角および $5 \mu \mathrm{m}$ の 3 種類のストッパを設けたサンプルについて評 価, 比較を行った. 全評価サンプルのうちカンチレバー の復元力より大きな表面間力を有するサンプルの割合を 付着率 (Sticking Rate) と定義し, ストッパの寸法 ( 1 辺 の長さ) との関係をまとめた結果を Fig. 10 に示す. 20 $\mu \mathrm{m}$ 角のストッパ付きサンプルの付着率を 1 とし, ほか のサンプルの付着率をこれに対する相対值で表わした.評 価サンプル数は各 30 個である. $5 \mu \mathrm{m}$ 角のストッパ付き サンプルでは付着率はゼロであり，20 $\mathrm{m}$ 角および 10 $\mu \mathrm{m}$ 角のストッパ付きサンプルに比べて表面間力は十分 小さい：これは, Fig. 2〜Fig. 4 からわかるように $20 \mu \mathrm{m}$ 角および $10 \mu \mathrm{m}$ 角のストッパは上面に平坦な部分があ って台形状であるのに対し， $5 \mu \mathrm{m}$ 角のストッパはピラ ミッド状であるという大きな形状の相違に関係している ものと考えられる，すなわち，前者ではストッパと電極 との接触はストッパの最前部で起こり, 線接触であるの に対し, 後者ではピラミッドの頂上部で接触が起こるた め前者に比べて接触面積 $S$ が著しく小さく, その結果全 表面間力 $F$ が非常に小さくなるものと考えられる. 以上 のように, 接触部の形状はマイクロ構造における表面間 力の大きさに著しい影響を与えることがわかった。

\section{6. 結 言}

本論文の特徵を要約するとつぎのようである.

（1）単結晶シリコンを加工して作ったカンチレバーに よって支持された可動部と, これと微小な空吵を隔 てて形成した対向電極を有する表面間力測定用のマ イクロ構造を作成し, 可動部と対向電極との間に電 圧を加えて静電気力によって表面間力を評価する方 法を考案した。

（2）上記の評価方法によって各種条件での表面間力を 測定し；素子表面に物理吸着した水分子同士の間に 働く引力が表面間力に大きな寄与をすることを確認 した.

（3）素子の高温加熱処理(約 $180^{\circ} \mathrm{C}$ ) や素子表面の疎水 化処理などによって表面への物理吸着水の量を低減 することにより表面間力を低減できることがわかっ た.

（4）接触部表面の形状，特に接触面積の大小が表面間 力に大きな影響を及ぼすことが確認できた。たとえ ば，接触面積を非常に小さくできるピラミッド状の ストッパを設けることにより表面間力を大きく低減 できた。

\section{参 考 文 献}

1) Y. Tai and R. S. Muller : Frictional Study of IC-processed Micromotors, Sensors and Actuators, A21-A23, 180/183 (1990)

2) M. Mehregany, S. M. Phillips, E. T. Hsu and J.H. Lang: Operation of Harmonic Side-Drive Micromotors Studied through Gear Ratio Measurements, Technical Digest, 6th Int. Conf. Solid-State Sensors and Actuators, 59/62 (San Francisco, CA, June 1991)

3) H. Guckel, J. J. Sniegowski, T. R. Christenson, S. Mohney and T.F. Kelly: Fabrication of Micromechanical Devices from Polysilicon Film with Smooth Surfaces, Sensors and Actuators, 20, 117/122 (1989)

4) P. R. Scheeper, J. A. Voorthuyzen and P. Bergveld: Surface Forces in Micromachined Structures, Proc. Micromechanics Europe '90, 47/52 (Berlin, November (1990)

5）奥山, 増田, 東谷, 近沢, 金澤：2 粒子間相互作用, 粉体工学 会誌, 22, 7, 451/475 (1985)

6) 神保元二：1個の粒子としての粉体の付着力測定法の比 較検討, 材料, 16, 164, 9/15（1967） 


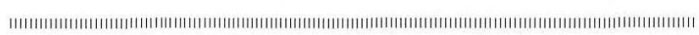

\section{[著 者 紹 介]}

\section{土 谷 茂 樹 (正会員)}

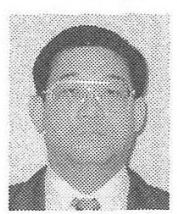

1979 年, 大阪大学大学院基礎工学研究科 物性学分野修士課程修了。同年(株) 日立製 作所日立研究所入社。湿度センサ，速度， 加速度センサなどの研究に従事. 92 年より (株) 日立製作所知的所有権本部勤務, 現在 に至る、応用物理学会の会員。

\section{鈴 木 清 光 (正会員)}

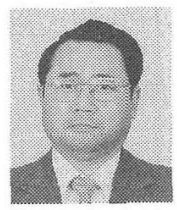

1965 年, 近畿大学理工学部機械工学科卒 業。同年(株) 日立製作所日立研究所入社, 現在に至る。エアフローセンサ，圧力セン サ，加速度センサなど自動車用センサの研 究に従事. SAE, 自動車技術会, 日本機械 学会などの会員。

\section{嶋田智 (正会員)}

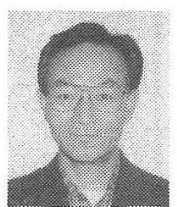

1969 年, 茨城大学工学短期大学部電気科 卒業，(株）日立製作所に入社，日立研究所 において工業計器, 自動車用センサの研究 に従事, 現在に至る。精密機械学会の会員.

\section{三木 政 之}

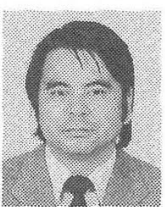

1971 年，茨城県立勝田工業高等学校卒 業。同年(株)日立製作所日立研究所入社, 現在に至る。エアフローセンサ, 空燃比セ ンサ，加速度センサなどの自動車用センサ の研究に従事。

松本昌大

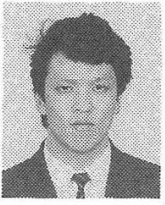

1983 年, 愛媛県立松山工業高等学校卒 業. 同年(株) 日立製作所日立研究所入社, 現在に至る。角速度, 速度, 加速度など物 理量センサの研究に従事。

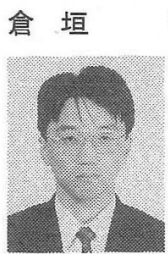

1991 年, 豊橋技術科学大学大学院修士課 程修了。同年(株)日立製作所日立研究所入 社，現在に至る。加速度など物理量センサ の研究に従事。 